\title{
PELAKSANAAN EVALUASI KEBIJAKAN BERDASARKAN \\ PERATURAN BAZNAS NOMOR 2 TAHUN 2016 TENTANG PEMBENTUKAN DAN TATA KERJA UNIT PENGUMPUL ZAKAT (UPZ) PADA UPZ BAZNAS KOTA MALANG
}

\author{
SLAMET* \\ Program Studi Magister Ilmu Administrasi \\ Universitas Islam Malang \\ *Email: slamet.spsi17@gmail.com
}

\begin{abstract}
ABSTRAK
Penelitian ini bertujuan untuk mengetahui dan mendeskripsikan pelaksanaan evaluasi berdasarkan peraturan BAZNAS No. 2 Tahun 2016 pada UPZ BAZNAS Kota Malang. Untuk mengetahui dan mendeskripsikan penghambat dalam pelaksanaan evaluasi berdasarkan peraturan BAZNAS No. 2 Tahun 2016 pada UPZ BAZNAS Kota Malang. Untuk mengetahui dan mendeskripsikan dampak implikasi terhadap eksistensi berdasarkan pada peraturan BAZNAS No. 2 Tahun 2016 pada UPZ BAZNAS Kota Malang. Teori yang digunakan dalam pelaksanaan evaluasi kebijakan ini mengacu pada teori William N. Dunn bahwasanya dalam evaluasi terdapat kriteria yaitu, efektivitas, efisiensi, kecukupan, perataan, responsivitas dan ketepatan.

Pendekatan menggunakan pendekatan kualitatif dengan metode deskriptif. Sedangkan teknik pengumpulan data menggunakan observasi, wawancara dan studi pustaka. Analisis data menggunakan model Miles, Huberman \& Saldana (2014). Uji keabsahan data menggunakan trianggulasi teknik.

Hasil penelitian menunjukan bahwa evaluasi kebijakan berdasarkan pada Peraturan BAZNAS Nomor 2 Tahun 2016 masih belum berjalan secara optimal. Minimnya sumberdaya manusia (SDM) yang dimiliki oleh pengurus UPZ, minimnya waktu yang dimiliki oleh pengurus UPZ, dan secara kelembagaan UPZ masih belum bisa mandiri. Sehingga hal ini dapat menurunkan eksistensi UPZ terhadap kepercayaan muzaki, sehingga muzaki belum bisa sepenuhnya percaya atas kehadiran UPZ di lingkungan masyarakat.
\end{abstract}

Kata Kunci: Kebijakan Publik, Evaluasi Kebijakan, Unit Pengumpul Zakat (UPZ) 


\section{PENDAHULUAN}

Zakat merupakan sebuah ibadah maliyah ijtima'iyah yang memiliki posisi sangat penting, strategis dan menentukan jika dicermati dari segi ajaran Islam maupun menurut sisi pembangunan kesejahteraan umat. Menurut istilah, zakat memiliki makna mengeluarkan sebagian harta (tertentu) yang telah diwajibkan oleh Allah SWT buat diberikan kepada orang-orang yang berhak menerimanya menggunakan kadar, haul tertentu, memenuhi syarat dan rukunnya (Kemenag RI, 2013: 12).

Zakat merupakan sebuah ibadah yang mempunyai nilai ganda, hablum minallah (vertikal) dan hablum minannas (horizontal), dimensi ritual sosial. Artinya, orang yang selalu menunaikan zakat akan menaikkan keimanan dan ketaqwaan kepada Allah SWT, menumbuhkan rasa kepedulian sosial, dan membangun hubungan sosial kemasyarakatan.

Sedangkan pada KBBI zakat merupakan sebagian berdasarkan harta yang wajib dikeluarkan oleh seorang muslim lalu diberikan pada orang yang kurang mampu (8 Asnaf) berdasarkan kadar yang sudah ditetapkan oleh syara'. Sejumlah harta yang dimaksud sudah diatur dalam syara'. Sedangkan yang dimaksud dengan orang yang beragama Islam tidak semua berkewajiban menunaikan zakat, malain mereka yang memiliki kemampuan atau golongan aghniya (Kemenag RI, 2013: 12-13).

Zakat dalam Islam merupakan suatu kewajiban bagi yang mampu, lantaran salah satu rukun pada Islam merupakan menunaikan zakat bagi yang mampu. Pada Al-Qur'an tidak sedikit ayat yang menjelaskan tentang perintah zakat, salah satunya tertuang dalam surat at-Taubah ayat 103, yang artinya;

"Ambillah zakat dari sebagian harta mereka. Dengan zakat itu kamu membersihkan dan mensucikan mereka. Dan berdoalah untuk mereka. Sesungguhnya doa kamu itu (menjadi) ketentraman jiwa bagi mereka. Dan Allah Maha Mendengar lagi Maha Mengetahui".

Islam sangat memperhatikan dan senantiasa berperan dalam 
pengentasan kemiskinan pada beberapa negara Islam di dunia termasuk Indonesia, walaupun notabenenya Indonesia bukan negara Islam, pengelolaan zakat di Indonesia diatur pemerintah, melalui UU 23 Tahun 2011 mengenai pengelolaan zakat. Hal ini merupakan suatu bukti kepedulian pemerintah terhadap masyarakat serta meminimalisir permasalahan yang akan timbul dikemudian hari, mengingat potensi zakat di Indonesia sangat tinggi yaitu mencapai 230 triliun per tahunnya.

Terkandung dalam pasal 1 ayat bahwasanya BAZNAS merupakan lembaga pengelola zakat secara nasional. Lebih mendalam yang terkandung dalam BAB II tentang BAZNAS, bagian ketiga tentang BAZNAS Provinsi dan BAZNAS Kabupaten/Kota dibuat oleh Menteri ataupun pejabat yang ditunjuk atas usulan Bupati/Walikota selepas mendapatkan pertimbangan BAZNAS (UU 23, 2011). Selayaknya organisasi pada umumnya dalam memaksimalkan tugas dan fungsinya, BAZNAS membantuk Unit Pengumpul Zakat
(UPZ). Dalam pasal 1 ayat (9) dijelaskan bahwa UPZ adalah satuan organisasi yang dibuat BAZNAS dalam membantu pengumpulan zakat (UU 23, 2011).

Terkandung pada pasal lima bahwa BAZNAS Kabupaten/Kota membangun UPZ BAZNAS Kabupaten/Kota dalam instansi pemerintah maupun swasta, yang terdiri atas, 1) tempat kerja instansi vertikal; 2) kantor satuan pemerintah wilayah; 3) BUMD; 4) perusahaan swasta; 5) pendididikan dasar atau nama lainnya; 6) masjid, musholla, langgar, surau atau nama lainnya, pada taraf Kabupaten/Kota (PERBAZNAS 2, 2016). Dengan demikian BAZNAS Kota Malang pada hal ini selaku eksekutor dalam menjembatani kepanjangan tangan pemerintah daerah pada masyarakat melalui UPZ. Sampai dengan ketika ini jumlah UPZ yang terdaftar pada BAZNAS Kota Malang masih kurang dari 100. Jika mengacu dalam jumlah masjid Jami' yang terdapat pada Kota Malang ada sekitar 600 masjid. Hal ini masih sangat jauh berdasarkan ekspektasi, maka dari itu BAZNAS Kota Malang kedepannya 
hendaknya melakukan evaluasi serta inovasi baru dalam rangka menaikkan jumlah UPZ di lingkungan kerjanya, semakin banyak UPZ maka akan semakin merata donasi BAZNAS bagi rakyat Kota Malang.

Berdasarkan penelitian yang dilakukan oleh Suparman \& Romadhon (2019) hasil penelitian mengambarkan bahwa kebijakan tersebut evaluasi atas PERBAZNAS Nomor 2 Tahun 2016 masih belum bekerja secara maksimal. Hal ini karena muzaki yang berpotensi belum percaya kepada UPZ UNPAD dan mustahik belum semuanya

\section{TINJAUAN PUSTAKA}

\subsection{Kebijakan Publik}

Kebijakan publik merupakan sebuah rangkaian keputusan yang diambil oleh seseorang atau sekelompok orang tertentu urntuk mewujudkan tujuan-tujuan tertentu terhadap masyarakat

(Taufiqurokhman, 2014:4).

Kebijakan publik dalam sebuah dimensi proses, lingkungan kebijakan, hirarki dan aktor kebijakan publik pada khususnya merasa puas dengan pelayanan dan hadiah dana zakat, infaq dan sedekah (ZIS). Selain itu, ketersediaan sumber daya manusia (SDM) pada UPZ UNPAD masih terbatas terutama di jajaran pengurusnya.

Dibentuknya BAZNAS Kota Malang adalah suatu upaya dalam mencapai daya guna, hasil guna, dan akuntabilitas pada pengelolaan dana ZIS di Kota Malang sehingga dapat menaikkan peran serta umat Islam di Kota Malang dalam rangka meningkatkan pembangunan insan seutuhnya menggunakan pengelolaan dana ZIS.

dalam framework pemerintahan dan ketatanegaraan republik Indonesia, merupakan sebuah hal yang sangat penting untuk diketahui sebagai salah satu pijakan dasar dalam memahami lebih mendalam, tanpa terkecuali kebijakan publik sebagai sebuah disiplin ilmu yang harus dipahami diawal, khususnya terkait konsep-konsep kebijakan publik (Kadji, 2015:5). Sedangkan menurut Chandler \& Plano, sebuah kebijakan 
publik merupakan sebuah pemanfaatan yang sangat strategis terhadap sumberdaya yang ada dalam memecahkan permasalahanpermasalahan publik atau bahkan masalah pemerintah (dalam Keban, 2008:60).

\subsection{Implementasi}

Kebijakan Publik

Tahapan terpenting dalam sebuah kebijakan terletak pada tahapan implementasi, hal ini dikarenakan sebuah kebijakan yang diterapkan bisa dilakukan pengukuran sejauh mana sebuah kebijakan berjalan sesuai dengan apa yang telah diinginkan dan sesuai dengan tujuan-tujuan yang telah disepakati bersama sebelumnya. Menurut salah seorang tokoh yaitu Jones menjelaskan bahwa implementasi kebijakan merupakan sebuah kemampuan dalam membentuk suatu hubungan lebih mendalam, dalam sebuah rangkaian sebab-akibat yang menghubungkan suatu tindakan dengan sebuah tujuan (dalam Suparno, 2017:15).

Menurut Mazmanian \& Sabatier pelaksanaan sebuah keputusan kebijakan dasar pada umumnya dibentuk dalam UU, berbentuk perintah atau keputusan eksekutif. Keputusan tersebut mengidentifikasikan sebuah permasalahan yang ingin diselesaikan, menyebutkan secara tegas tujuan atau sasaran yang ingin dicapai, dan melakukan berbagai cara dalam mengatur proses pelaksanaan sebuah implementasi (dalam Suparno, 2017:15).

Sedangkan dari Wahab sebuah proses implementasi kebijakan sesungguhkan tidak terpaku hanya dalam konduite badan administratif yang bertanggungjawab dalam melaksanakan program-program dan membentuk sebuah kepatuhan terhadap sebuah kelompokkelompok sasaran, tetapi juga menyangkut jaringan kekuatan politik, ekonomi, dan sosial yang secara pribadi atau bahkan tidak langsung bisa berdampak pada konduite semua pihak yang terlibat, dan dalam akhirnya berdampak terhadap tujuan baik yang diharapkan maupun tidak diharapkan (dalam Taufiqurokman, 2015:15). 


\subsection{Evaluasi Kebijakan Publik}

Evaluasi kebijakan publik merupakan suatu proses yang cukup rumit dan panjang, memiliki tahapan kebijakan yang tidak akhir, tetapi terdapat tahapan berikutnya yang memungkinkan lahirnya reformasi dalam melahirkan sebuah kebijakankebijakan baru (Winarno, 2013: 93). Menurut Anggara (2014: 121) sebuah evaluasi kebijakan dicermati sebagai salah satu kegiatan fungsional. Artinya, sebuah evaluasi kebijakan hanya dilakukan dalam tahap akhir, namun pula dilakukan dalam seluruh proses kebijakan tersebut. Evaluasi kebijakan meliput program-program yang sudah diusulkan dalam meneyelesaikan beberapa permasalahan-perseteruan kebijakan, implementasi, dan efek dari suatu kebijakan.

Gambaran utama dalam sebuah evaluasi yaitu membuat penilaian yang memiliki kepastian sifat berupa evaluatif, dengan demikian penilaian memiliki beberapa karakteristik yang berbeda dengan metode-metode analisis kebijakan lainnya (Dunn, 2003:608-609), Adapun karakteristik dalam evaluasi kebijakan publik sebagai berikut:

1. Fokus Nilai, sebuah penilaian tentu tidak sama menggunakan pengamatan, sebuah penilaian difokuskan pada evaluasi yang dikaitkan dengan kepentingan atau nilai dari suatu kebijakan dan program. Evaluasi adalah salah satu usaha dalam menetapkan manfaat atau kepentingan sosial kebijakan atau program. Evaluasi bukan hanya buat mencari berita tentang hasil dari sebuah kebijakan yang diantisipasi atau tidak. Ketepatan tujuan dan sasaran sebuah kebijakan senantiasa menuai indikasi tanya, penilaian meliputi prosedur-prosedur dalam mengevaluasi tujuan dan sasaran itu sendiri.

2. Interdependensi Fakta-Nilai, tuntutan evaluasi tergantung baik "fakta" maupun "nilai". Dalam mengambarkan sebuah kebijakan atau program sudah mencapai tingkat kinerja yang maksimal bahkan sebaliknya, bukan semata-mata manfaat 
dari kebijakan bagi sejumlah individu, kelompok atau semua masyarakat, buat mengungkapkan hal tersebut, harus didukung sang bukti bahwa hasil kebijakan yang sahih-benar terjadi adalah persesuaian berdasarkan aksiaksi yang dilakukan buat mengatasi konflik tertentu. Oleh karena itu pemantauan adalah salah satu pada pelaksanaan evaluasi.

3. Orientasi Masa Kini dan Masa Lampau, tuntutan evaluatif, tidak sama dengan tuntutan advokatif, diarahkan pada output sekarang dan masa lalu, dibandingkan hasil pada masa depan. Evaluasi bersifat retrospektif dan sehabis aksiaksi dilalukan. Rekomendasi yang juga meliputi permispermis nilai, bersifat prospektif dan dibuat sebelum aksi-aksi dilakukan.

4. Dualitas Nilai, nilai-nilai yang mendasari tuntutan penilaian memiliki mutu ganda, lantaran mereka ditinjau menjadi tujuan dan sekaligus cara. Nilai-nilai acapkali ditata di dalam suatu hirarki yang mencerminkan keadaan dan saling ketergantungan antar tujuan dan sasaran.

Dalam penelitian ini peneliti akan mengaplikasikan sebuah teori evaluasi kebijakan dari teori William N. Dunn, yang mana dalam sebuah evaluasi kebijakan masih ada enam kriteria, Adapun buat lebih rinci kriteria tersebut menjadi berikut: 
Tabel 1. Kriteria Evaluasi Kebijakan

\begin{tabular}{|c|c|c|}
\hline Tipe Kriteria & Pernyataan & Ilustrasi \\
\hline Efektivitas & $\begin{array}{l}\text { Apakah hasil yang } \\
\text { diinginkan telah dicapai? }\end{array}$ & Unit pelayanan \\
\hline Efisiensi & $\begin{array}{l}\text { Seberapa banyak usaha yang } \\
\text { diperlukan untuk mencapai } \\
\text { hasil yang diinginkan? }\end{array}$ & $\begin{array}{l}\text { Unit biaya } \\
\text { Unit manfaat } \\
\text { Rasio biaya } \\
\text { manfaat }\end{array}$ \\
\hline Kecukupan & $\begin{array}{l}\text { Seberapa jauh pencapaian } \\
\text { hasil yang diinginkan } \\
\text { memecahkan masalah? }\end{array}$ & $\begin{array}{l}\text { Biaya tetap } \\
\text { (masalah tipe I) } \\
\text { Efektivitas tetap } \\
\text { (masalah tipe II) }\end{array}$ \\
\hline Perataan & $\begin{array}{l}\text { Apakah biaya dan manfaat } \\
\text { didistribusikan dengan } \\
\text { merata kepada kelompok- } \\
\text { kelompok tertentu? }\end{array}$ & $\begin{array}{l}\text { Kriteria Pareto } \\
\text { Kriteria Kaldor } \\
\text { Hiks } \\
\text { Kriteria Rawls }\end{array}$ \\
\hline Responsivitas & $\begin{array}{l}\text { Apakah hasil kebijakan } \\
\text { memuaskan, preferensi atau } \\
\text { nilai kelompok-kelompok } \\
\text { tertentu? }\end{array}$ & $\begin{array}{l}\text { Konsistensi } \\
\text { dengan survei } \\
\text { warga negara }\end{array}$ \\
\hline Ketepatan & $\begin{array}{l}\text { Apakah hasil (tujuan) yang } \\
\text { diinginkan benar-benar } \\
\text { berguna atau bernilai? }\end{array}$ & $\begin{array}{l}\text { Program publik } \\
\text { harus merata dan } \\
\text { efisien }\end{array}$ \\
\hline
\end{tabular}

\subsection{Kerangka Konsep Evaluasi Kebijakan Publik}

Sebagaimana yang telah disampaikan sebelumnya bahwa fokus pada penelitian ini pada kebijakan yang dikeluarkan oleh BAZNAS yaitu PERBAZNAS Nomor 2 Tahun 2016 tentang Pembentukan dan Tata Kerja Unit Pengumpul Zakat. Sebagaimana yang sudah tertuang pada pasal 7 ayat (1) dan pasal 8 tentang tugas dan fungsi UPZ yang sebagaimana dimaksud merupakan keberadaan UPZ buat membantu menghimpun, mengelola, mendistribusikan, mendayagunakan dan lain sebagainya tentang dana zakat, infaq dan sedekah (ZIS). Permasalahan ini kemudian dispesifikkan pada UPZ dalam tingkat Kabupaten/Kota. 
Upaya ini dilakukan terkait kemaslahatan umat, dalam hal ini terkait pelaksanaan evaluasi terutama bagi kemaslahatan umat kebijakan tersebut, guna Islam di Kota Malang pada mempertegas tujuan kebijakan yang khususnya. Adapun agar lebih telah dirumuskan sebelumnya, mudah memberikan pemahaman supaya amanat yang terkandung kepada pembaca maka, kerangka dalam kebijakan tersebut bisa kosep evaluasi kebijakan dikemas diselenggarakan sesuai dengan yang dalam bentuk bagan, untuk lebih telah ditetapkan dan maksimal serta rinci bagan tersebut akan dipaparkan memiliki dampak positif terhadap sebagai berikut ini:

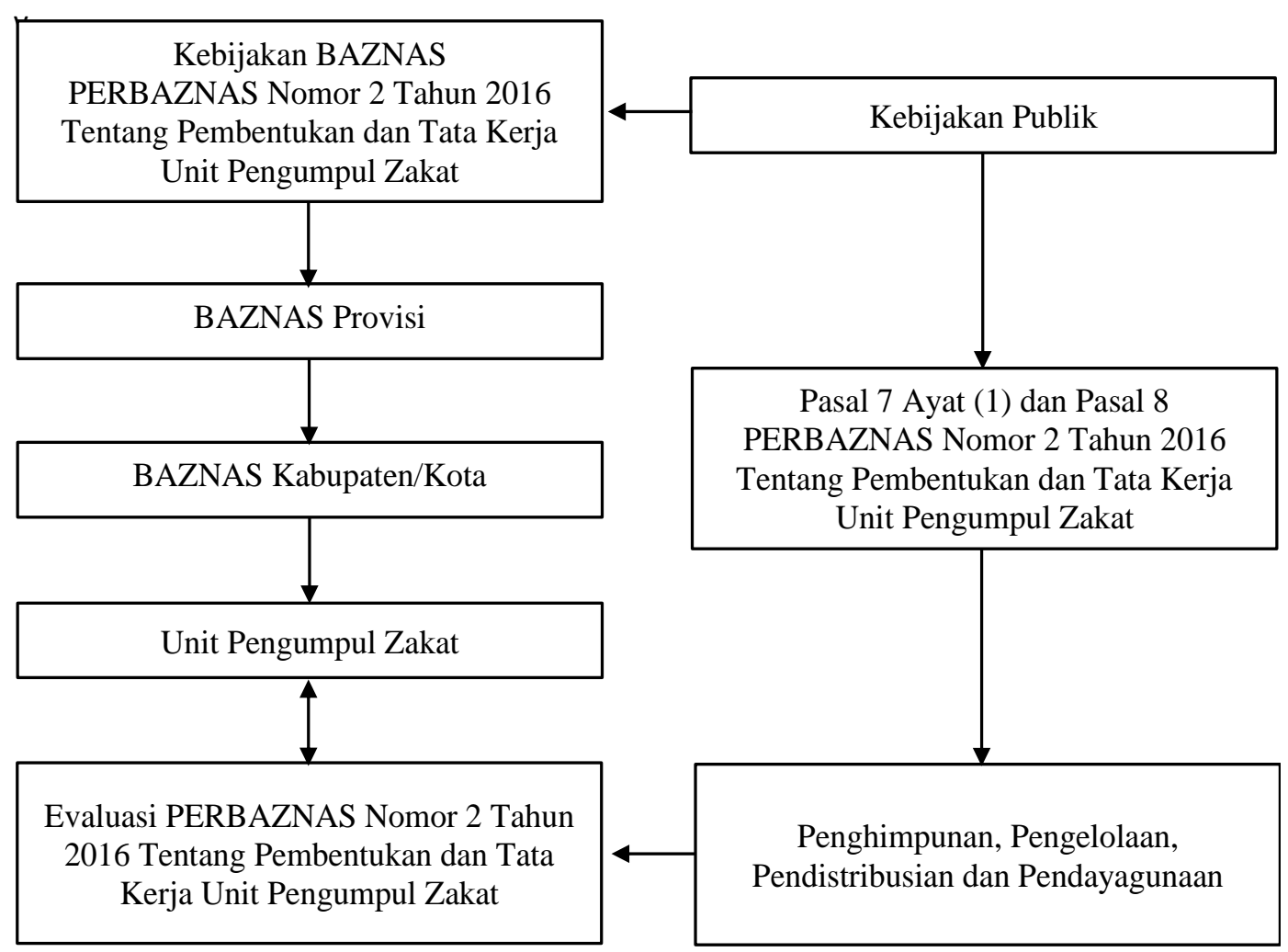

Gambar 1. Kerangka Konsep Evaluasi Kebijakan Publik 


\section{METODE PENELITIAN}

Pendekatan yang digunakan dalam penelitian ini adalah pendekatan kualitatif deskriptif. Menurut Creswell penelitian kualitatif merupakan suatu proses inkuiri buat memahamkan menurut tradisi-tradisi inkuiri metodologis yang jelas yang mengeksplorasi permasalahan sosial dan manusia (dalam Ahmadi, 2018:15). Penelitian dilakukan dalam UPZ BAZNAS Kota Malang. Pengumpulan data pada penelitian ini menggunakan teknik observasi, wawancara, dan studi pustaka. Analisis data yang digunakan pada penelitian ini ini yaitu memakai model Miles, Huberman dan Saldana (2014) yang mana pada analisisnya terdiri atas, data reduction, data display \& conclusion, drawing/verification. Sedangkan uji keabsahan data pada penelitian ini adalah dengan menggunakan teknik triangulasi. Teknik triangulasi teknik digunakan untuk melakukan pengujian kredibilitas data, dilakukan dengan cara mengecek data kepada sumber yang sama dengan memakai teknik yang berbeda (Sugiyono, 2011:274).

\section{HASIL PENELITIAN DAN PEMBAHASAN}

\subsection{Pelaksanaan Evaluasi}

Untuk mengetahui sejauhmana pelaksanaan suatu program dalam sebuah organisasi adalah dengan melakukan evaluasi. Seperti halnya UPZ BAZNAS Kota Malang, dalam rangka meningkatkan program kerjanya maka perlu dilakukan evaluasi yang terstruktur dan sudah diagendakan sebelumnya. Pelaksanaan evaluasi yang dilakukan oleh UPZ berdasarkan pada aturan yang telah ditetapkan oleh BAZNAS yaitu, Peraturan BAZNAS Nomor 2

Tahun 2016 tentang Pembentukan dan Tata Kerja Unit Pengumpul Zakat. Sebagaimana yang telah tertuang dalam pasal 11 ayat (6) poin b yakni, pengurus UPZ bertugas melakukan evaluasi atas pelaksanaan tugas dan fungsi UPZ.`

Dalam hal ini UPZ melaksanakan tugas dan fungsinya yakni, membantu BAZNAS dalam melakukan penghimpunan, pendistribusian dan pengelolaan serta 
mendayagunakan dana ZIS. Salah satu peran penting UPZ dalam mengemban tugas beserta fungsinya yaitu, mensejahterakan mustahik di lingkungan pemerintah Kota Malang, dengan cara mendistribusikan dana ZIS yang telah dihimpun dari muzaki kemudian ditasyarufkan kepada para mustahik yang memenuhi syarat di wilayah kerja masing-masing UPZ. Dalam penelitian ini evaluasi yang diterapkan berdasarkan pada teori William N. Dunn, dimana dalam teorinya sebuah keberhasilan dalam pelaksanaan sebuah evalaluasi memehuhi beberapa syarat, yaitu sebuah evaluasi harus memenuhi enam kriteria, diantaranya mmiliki efektifitas yang baik, memiliki efisien, memiliki kecukupan, harus merata, dan harus memiliki responsivitas yang tinggi serta memiliki ketetapan.

Kriteria efektivitas, dalam melaksanakan sebuah evaluasi terhadap suatu kebijakan melihat pada pembahasan yang mencakup hasil dari kebijakan tersebut. Maksudnya yaitu kebijakan yang telah diimplementasikan akan mendapatkan hasil yang sesuai dengan tujuan-tujuan dan sasaran dari kebijakan itu sendiri. Berdasarkan dari kriteria efektivitas proses pelaksanaan evaluasi yang dilakukan oleh UPZ BAZNAS Kota Malang masih belum sempurna, diantaranya yaitu, terdapat beberapa UPZ yang masih belum memiliki standar operasional prosedur (SOP) yang jelas tentang program kerja, kegiatan pelaksanaan evaluasi masih belum tersetruktur, sehingga dalam pelasksanaan evaluasi masih belum bisa berjalan dengan baik. Hal semacam ini tidak bisa dibiarkan berlarut-larut karena akan menimbulkan efek yang kurang baik bagi lembaga di mata masyarakat.

Kriteria efisiensi, pelaksanaan evaluasi mengacu pada "seberapa banyak usaha yang diperlukan untuk mencapai hasil yang diinginkan?" UPZ melakukan beberapa langkahlangkah alternatif, diantaranya yaitu, melakukan kaderisasi. Objek kaderisasi dalam hal ini yaitu remaja masjid, serta bekerjasama dengan karangtaruna setempat tentu hal ini akan sangat efisien yaitu efisien biaya dan manfaat. Selain itu juga bisa bekerjasama dengan pihak 
ketiga terkait pelaksanaan program kerja, selama ini potensi yang besar tetapi belum bisa terjamah oleh UPZ yaitu bekerjasana dengan perusahaan yang berada di lingkup kerja UPZ. Jika pengurus UPZ bisa membaca potensi tersebut maka nilai penghimpunan tentu juga akan meningkat dengan kata lain maka akan semakin banyak penerima manfaat yang bisa terbantu.

Kriteria kecukupan, pelaksanaan evaluasi mengacu pada "seberapa jauh pencapaian hasil yang dikehendaki dapat mengatasi suatu masalah?" Dalam mengatasi masalah yang selalu ada pengurus UPZ dituntut untuk selalu dapat menemukan alternatif solusi. Berdasarkan hasil evaluasi yang dilakukan oleh pegurus UPZ mendapatkan beberapa rekomendasirekomendasi terkait pemecahan permasalahan yang sedang dihadapi terutama permsalahan terkait program kerja UPZ. Namun sayangnya rekomendasi tersebut belum bisa menyelesaikan semua permasalahan yang dihadapi, misalnya yaitu, terdapat beberapa UPZ belum mendokumentasikan data-data mustahik. Sehingga pada waktu akan melakukan pentasyarufan selalu melakukan pendataan ulang.

Kriteria perataan, pelaksanaan evaluasi dalam suatu organisasi harus dilakukan oleh semua anggota organisasi, entah itu unsur pimpinan maupun unsur pelaksana atau staff. Pelaksanaan evaluasi pada UPZ sampai saat ini masih belum bisa maksimal karena masih terdapat UPZ yang melakukan evalusi masih belum merata terhadap semua anggotanya. Misalnya, melakukan evaluasi hanya pada unsur pimpinan (ketua, wakil), tentu hal ini masih belum bisa dikatakan merata. Selain itu untuk ukuran UPZ kelurahan biasa belum merata dalam memberikan informasi kepada masyarakat.

$$
\text { Kriteria responsivitas, }
$$
pelaksanaan evaluasi mengacu pada “apakah hasil kebijakan memuaskan kebutuhan, preferensi atau nilai kelompok tertentu?" Dalam pelaksanaan evaluasi kebijakan pengurus UPZ harus bersifat professional dalam membuat sebuah kebijakan, jangan sampai kebijakan 
yang dibuat nantinya hanya akan menguntungkan kelompok tertentu, sehingga dengan demikian dalam membuat kebijakan hendaknya sudah melakukan survei lapangan terlebih dahulu. Beberapa UPZ sudah melakukan prosedur dengan baik, selain keputusan bersama diimbangi dengan data lapangan dengan melakukan survei langsung di lapangan.

Kriteria ketepatan, pelaksanaan evaluasi mengacu pada "apakah hasil (tujuan) yang diinginkan benar-benar berguna atau bernilai?" Hasil dari pelaksanaan evaluasi terkait realisasi program harus benar-benar sesuai dengan sasarannya. Sampai dengan saat ini dalam menyampaikan ketetapan sudah bagus tetapi hal yang sangat disayangkan yaitu dalam penyampaian informasi terkait ketetapan masih belum merata. Hal ini terjadi hampir diseluruh UPZ BAZNAS Kota Malang. Terkadang informasi hanya terbatas kepada orang-orang terdekat saja.

\subsection{Kendala dalam Pelaksanaan \\ Evaluasi \\ Dalam perjalanannya hampir} semua organisasi pasti memiliki kendala masing-masing sesuai dengan tingkatan organisasi tersebut, semakin besar organisasi tersebut maka semakin komplek masalah atau kendala yang dihadapinya. Sepeti halnya UPZ BAZNAS Kota Malang. Sampai dengan saat ini, belum semua UPZ melakukan evaluasi sesuai dengan tugas dan fungsinya seperti yang tertuang dalam pasal 11 ayat (6) poin b yakni, pengurus UPZ bertugas melakukan evaluasi atas pelaksanaan tugas dan fungsi UPZ. Berdasarkan informasi yang telah dikemukan oleh ketua UPZ AzZahra Kelurahan Kebonsari, yaitu;

“.....selama ini kami
melakukan evaluasi setelah
melakukan kegiatan saja, karena
memang kondisinya semuanya
bekerja. Untuk pelaksanaan
program saja kami memilih
waktu di hari libur, misalnya
hari sabtu, minggu atau tannggal
merah pada waktu peringatan
hari-hari besar" (WS01-101020).

Berdasarkan hasil wawancara yang telah dilakukan, bisa dikatakan dalam pelaksanaan evaluasi masih 
kurang efektif, karena pelaksanaan evaluasi dilakukan hanya setelah pelaksanaan program saja. Seharusnya pelaksanaan evaluasi yang efektif setelah kegiatan dilakukan evaluasi selain itu terdapat evaluasi yang sudah dijadwalkan, misalnya evaluasi bulanan, per tiga bulanan, per semester dan tahunan.

Selain itu, informasi selanjutnya disampaikan oleh sekretaris UPZ AlMukhlisin, yang mana dalam pelaksanaan wawancara beliau menyampaikan bahwa;

"Kami ini keterbatasan SDM mas, karena memang pengurus UPZ al-Mukhlisin ini sudah termasuk tua-tua, jaman sekarang itu kan sudah maju, jadi harus mengikuti kemajuan teknologi, kalau yang tua-tua begini ya agak susah, sedangkan pemuda disini jarang yang mau dijadikan pengurus. Selama ini kami hanya memaksimalkan SDM yang ada saja mas, walaupun belum bisa dikatakan efisien setidaknya kami sudah berusaha" (WS02-121020).

Ujung tombak sebuah organisasi adalah SDM unggul, sehingga dengan demikian sebuah organisasi harus melakukan sebuah kaderisasi yang mana nantinya kader-kader muda ini yang akan meneruskan roda kehidupan sebuah organisasi. Selain melakukan kaderisasi dalam rangka meningkatkan SDM pengurus UPZ harus melakukan alternatif lain, misalnya mengikuti pelatihan tentang pengelolaan zakat, membuat forum diskusi tentang pengelolaan zakat ditingkat kelurahan atau RW. Sehingga dengan demikian akan meningkatkan SDM yang ada.

Informasi lain yang telah didapatkan oleh peneliti dari informan, selaku Pembina UPZ Masjid di Klayatan, sebagai berikut;

"Selama ini kita yang penting jalan aja dulu, terutama pada program pembagian rombongan lainnya sambil berjalan, karena memang penerima manfaatnya sudah tua-tua mas, mangkanya ya kita sebagai anggota UPZ tidak lama-lama dalam melakukan evaluasi terkait pelaksanaan program, selain terbatas oleh waktu bertemu juga penerimanya kebanyakan orang-orang tua-tua dan sudah pernah punya usaha sebelumnya. Pokoknya itu data kita kumpulkan lalu kami kirimkan ke kantor BAZNAS" (WS03111020).

Pada pelaksanaan program UPZ kurang begitu memperhatikan kuantitasnya yang penting jalan dulu, padahal kuantitas juga tidak jauh 
lebih penting jika dibandingkan dengan kualitas. Hal tersebut menurut pengurusa UPZ dianggap penerima manfaat sudah punya pengalaman dalam usahanya, sehingga mereka menganggap jika diberikan bantuan modal usaha sudah pasti berjalan dengan baik. Berdasarkan data yang telah diperoleh dari informan meraka langsung mengirimkan data semua kepada BAZNAS. Hal ini menunjukan bahwa mereka tidak melakukan arsip dokumen di UPZ.

Walaupun demikian, banyak langkah yang dilakukan oleh UPZ, seperti yang diungkapkan kembali oleh pembina UPZ di Klayatan, yaitu;

"Hampir semua anggota UPZ disini bekerja di siang hari, jadi kalau berkegiatan di siang hari sangat susah, karena sibuk dengan pekerjaan masingmasing, dan terkadang juga pulangnya malam. Tapi untuk mengatasi hal ini kita selalu ada koordinasi, dan sosialisasi dengan ketua RT setempat, hal ini sangat membantu" (WS03111020).

Pengurus UPZ notabenenya kebanyakan berasal dari masyarakat biasa, yang mana mereka juga harus memenuhi kebutuhan hidup sehariharinya. Dalam sebuah organisasi koordinasi merupakan salah satu hal yang penting untuk dilakukan. Adanya koordinasi ini sangat membantu kinerja UPZ walaupun belum secara maksimal, tetapi setidaknya sudah memiliki alternatif solusi dalam mengatasi permsalahan. Jika semua UPZ mau berkoordinasi dengan pemerintah setempat maka hasilnya akan lebih merata dalam pentasyarufan dana ZIS.

Selain itu, informasi yang telah kami dapatkan dari Kepala Bidang Pelaksana Pendistribusian dan Pendayagunaan BAZNAS Kota Malang, yaitu;

"Kebanyakan UPZ-UPZ BAZNAS Kota Malang ini masih tergolong baru, pengajuan pembentukan UPZ paling banyak selama saya di kantor ini, sekitar tahun 2019 dan tahun 2020 awal, maka kalau masyarakat belum respek itu wajar, hal ini merupakan sebuah tantangan bagi pengurus UPZ. Tetapi mas selama ini yang kami rasakan para UPZ sangat responsif terhadap keluhan masyarakat, walapun belum semuanya. Memang masih ada sebagian UPZ mengandalkan uluran tangan dari BAZNAS mas, ya tetap kita bantu" (WS04-141020) 
Dikarenakan memang kepengurusan UPZ BAZNAS Kota Malang masih tergolong masih banyak yang baru, maka hal ini sangat membutuhkan usaha yang keras terutama dalam pelaksanaan sosialisasi kepada masyarakat. Karena menggaet kepercayaan masyarakat itu tidak semudah yang telah direncanakan, harus membutuhkan strategi yang matang. Salah satu usaha yang dilakukan beberapa UPZ yaitu selalu responsif terhadap keluhan-keluhan msyarakat. Jika hal semacam ini dilakukan dengan maksimal dan konsisten maka tidak menuntut kemungkinan hal inilah yang menjadi ujung tombak UPZ dalam menarik simpatik para calon muzaki. Sisi lainnya yaitu masih ada beberapa UPZ yang masih belum mau berusaha sendiri dan masih menunggu uluran tangan dari BAZNAS. Padahal sudah jelas tugas UPZ membantu BAZNAS melakukan penghimpunan, pengelolaan, pendistribusian dan pendayagunaan. Walaupun demikian BAZNAS tetap membantu.
Informasi yang tidak kalah penting yaitu disampaikan kembali oleh ketua UPZ Az-Zahra, yaitu;

"Selama saya menjadi ketua UPZ kendala yang dihadapi banyak sekali mas, diantaranya yaitu dikarenakan kesibukan masing-masing, sehingga beberapa bidang pada UPZ belum berjalan dengan maksimal sesuai dengan yang diharapkan. Kita juga jarang mengikuti kegiatan even besama masyarakat, hal ini karena memang setiap kegiatan dilaksanan pada waktu jam kerja" (WS01-101020).

Banyak sekali kendala yang di hadapi oleh UPZ BAZNAS Kota Malang dan kendala yang dihadapi sangat kompleks dan bervariasi, sesuai dengan kondisi lingkup kerja masing-masing UPZ. Karena variasi dari permasalahan yang dihadapi oleh UPZ maka terkadang beberapa UPZ dalam menentukan kriteria mustahik kurang sesuai atau kurang tepat.

\subsection{Dampak Implikasi dari Kendala terhadap Eksistensi}

Tugas dan fungsi pengurus UPZ berdasarkan Peraturan BAZNAS Nomor 2 Tahun 2016 tentang Pembentukan dan Tata Kerja Unit 
Pengumpul Zakat tertuang dalam pasal 11 ayat (6) poin; a) menetapkan RKAT UPZ setelah mendapatkan pertimbangan penasehat; b) melakukan evaluasi atas pelaksanaan tugas dan fungsi UPZ; Menyusun perencanaan pengumpulan; d) melakukan pengumpulan zakat; e) melaksanakan pengelolaan data muzaki; f) melaksanakan sosialisasi dan edukasi zakat; g) memberikan layanan konsultasi zakat; dan h) menyerahkan hasil pengumpulan zakat ke BAZNAS sesuai dengan tingkatannya. Semuanya sudah diatur sehingga semua pengurus UPZ harus mengikuti kebijakan yang telah dibuat. Selain itu pengurus UPZ tidak boleh menyimpang dari koridor yang tercantum dalam aturan tersebut.

Berdasarkan pernyataan yang disampaikan oleh Kepala Bidang Pelaksana Pendistribusian dan Pendayagunaan, yaitu;

"Selama ini masih banyak UPZ yang pekerjaannya hanya menunggu program-program dari kita (BAZNAS), mereka nanti tinggal menjalankan saja, ibarat orang itu kalau gak digepok gak jalan mas" (WS04141020).

Tugas dan fungsi UPZ memiliki dampak atas eksistensinya yaitu terkait sistem pengelolaan dana ZIS yang dilaksanakan oleh UPZ. Berdasarkan pada aspek pengelolaan masih belum semua UPZ berjalan dengan maskimal, karena masih ada sebagian besar UPZ masih megandalkan dari BAZNAS tanpa mau berusaha melakukan pengumpulan sendiri, atau bisa dikatakan belum bisa mandiri seutuhnya. Jika UPZ tidak memiliki inovasi baru atau usaha untuk mandiri maka tidak akan bisa berkembang, tentu hal ini akan merugikan organisasi. Di era kemajuan teknologi seperti ini sebuah organisasi harus selalu melakukan inovasi-inovasi baru serta mengikuti perkembangannya, jika tidak maka akan terlindas oleh para pesaing.

Sistem yang diterapan pada pengelolaan, pendistribusian dan pendayagunaan cenderung masih kaku, terutama pada bidang pendistribusian dan pendayagunaan. Dalam semua program kerjanya UPZ 
harus menunjang tugas dan fungsi UPZ. Sebagian besar UPZ masih belum memiliki inovasi-inovasi baru terkait hal-hal baru yang sekiranya menjadi daya tarik para muzaki. Beberapa hal ini merupakan dampak

\section{KESIMPULAN}

Berdasarkan paparan di atas maka dapat disimpulkan bahwa proses evaluasi kebijakan yang dilaksanakan pengurus UPZ BAZNAS Kota Malang sampai dengan saat ini masih belum bisa berjalan secara optimal. Selain itu, beberapa faktor penghambat dalam pelaksanaan evaluasi kebijakan pada pengurus UPZ BAZNAS Kota Malang yaitu, minimnya

\section{DAFTAR PUSTAKA}

Abdoh, N. Muhammad. (2019). Tinjauan Filodofis Terhadap Undang-Undang Nomor 23 Tahun 2011 Tentang Pengelolaan Zakat. Cakrawala: Jurnal Studi Islam. Vol. 14 (2) 143-157.

Ahmadi, Rulam. (2018). Metodologi Penelitian Kualitatif. Yogyakarta: Ar-Ruzz Media. Anggara, Sahya. (2014). Kebijakan Publik. Bandung: CV. Pustaka Setia.

Ash-Shiddiqy, Teuku Muhammd Hasby. (2009). Pedoman Zakat. dari implikasi atas kendala-kendala yang ada terhadap eksistensi UPZ BAZNAS Kota Malang dalam jangka waktu pendek atau bahkan dalam jangka panjang.

sumberdaya manusia (SDM) yang dimiliki oleh pengurus UPZ, terkendala oleh waktu dan secara kelembagaan masih belum bisa mandiri. Sehingga hal ini dapat menurunkan eksistensi UPZ terhadap muzaki, sehingga muzaki belum bisa sepenuhnya percaya atas kehadiran UPZ di lingkungan masyarakat.

Semarang: PT. Pustaka Rizki Putra.

Dunn, W., N. (2003). Pengantar Analisis Kebijakan Publik. Edisi Kedua. Yogyakarta: Gajah Mada University Press.

Hafidhudhin, Didin. (2002). Zakat dalam Perekonomian modern. Jakarta: Gema Insani.

Kadji, Yulianto. (2015). Formulasi dan Implementasi Kebijakan Publik: Kepemimpinan dan Perilaku Birokrasi dalam Fakta Realitas. Gorentalo: UNG Press. 
Keban, Yaremias T. (2008). Enam Dimensi Strategi Administrasi Publik: Konsep, Teori dan Isu. Edisi Kedua Cetakan Pertama. Yogyakarta: Penertbit Gaya Media.

Miles, M. B., Huberman, A. M., \& Saldana, J. (2014). Qualitative Data Analysis: A Methods Sourcebook. Arizona. Includes Bibliographical Refrences and Index.

Peraturan BAZNAS Nomor 2 Tahun 2016 Tentang Pembentukan dan Tata Kerja Unit Pengumpul Zakat.

Rofiq, Ahmad. (2004). Fiqh kontekstual: Dari Normatif ke Pemaknaan Sosial. Yogyakarta: Pustaka Belajar.

Sari, Elsa Kartika. (2006). Pengantar Hukum Zakat dan Wakaf. Jakarta: PT Grasindo.

Sugiyono. (2011). Metode Penelitian Kuantitatif, Kualitatif dan $R \& D$. Bandung: Penerbit Alfabeta.

Suparman, Nanang \& Romadhon, Wildan. (2019). Evaluasi
Kebijakan Peratiran BAZNAS Nomor 2 Tahun 2016 Tentang Pembentukan dan Tata Kerja Unit Pengumpul Zakat di Universitas Padjadjaran. Jurnal Birokrasi \& Pemerintahan Daerah. Vol. 1 (1) 77-102.

Suparno. 2017. Implementasi Kebijakan Publik dalam Praktek. Semarang: Dwiputra Pustaka Jaya.

Taufiqurokhman. (2014). Kebijakan Publik: Pendelegasian Tanggungjawab Negara Kepada Presiden Selaku Penyelenggara Pemerintahan. Jakarta: Fakultas Ilmu Sosial dan Ilmu Politik Universitas Moestopo Beragama Pers.

Taufiqurokman. (2015). Pandeglang dalam Implementasi Kebijakan Peningkatan IPM. Jakarta: Fakultas Ilmu Sosial dan Ilmu Politi universitas Moestopo Beragama Pers.

Undang-Undang Republik Indonesia Nomor 23 Tahun 2011 Tentang Pengelolaan Zakat. 